\title{
The fundamental study of garnets: application for prospecting and economical estimation of diamond bearing kimberlites
}

Garanin, V.K., Kudriavtseva, G.P., Vasilyeva, E.R.

Department of Geology. Moscow State University. 119899 Vorob yovy Hills. Russia

\begin{abstract}
The searching of diamond deposits in the new kimberlite provinces requiests to develop and use new effective and ecological methods of the evaluation of diamond bearing kimberlites. For this purpose the complex methodology of the diamond bearing evaluation was created at Moscow University Diamond Deposits Laboratory.
\end{abstract}

\section{Introduction}

The one great discovery made at the end of 70s by Russian geologists - it was the Lomonosov deposit in the northern European part of Russia. This deposit belongs to vast diamondiferous province where further exploration revealed commercial grades of diamonds. There are many specific features of kimberlites in a new Arkhangelsk province (Verichev et al.,1991, Sablukov, 1995), for example, an almost complete absence deep xenoliths of ultrabasic and basic rocks. The minerals which were formed at disintegration of these deep xenoliths are very informative for searching of diamond bearing kimberlites. The garnets are often found in heavy fraction of kimberlites and allow to get important information about diamond potential of kimberlites on the base of the composition and physical properties of these minerals features.

\section{Methodology of garnet study}

A comprehensive method of investigations takes into account the morphological peculiarities, composition and properties of garnets and allows to apply a statistical approach for classifying of this mineral.

The complex methodology is realized in several stages.

At the first stage, samples are initially examined by binocular magnifier for separation the mineral grains by several signs: color, shape, the surface character and inner structure. Each of these signs has a definite genetical meaning. Histograms built on the morphological peculiarities based on the statistically representative material and allow to identify the mineral genetic groups and evaluate their distribution already on the first stage.

At the second stage, the application of optic-colorimetric method makes it possible to draw preliminary conclusions concerning the paragenesis of minerals and their occurrence.

At the final stage of the study, the application of the electron microprobe method on the statistically representable garnet samples allows to determine or confirm the mineral paragenesis. The discovered parageneses are detailed; the thermodynamic conditions of crystallization of separated parageneses are defined.

To determine the deep-seated parageneses at the final stage is advisable to apply the chemicalgenetic classification which has been designed at the Diamond Deposits Laboratory on the basis of numerous studies of garnet samples from deep-seated ultrabasic and basic rocks from kimberlite pipes of world diamond deposits (Garanin et al., 1991).

In this classification deep-seated diamond parageneses are highly diamondiferous if their portion in the entire selection is more than $90 \%$ of analyses in this chemical-genetic group; diamondiferous $90-50 \%$ and poor diamondiferous - less than 50\%. Non-diamondiferous garnet parageneses are those where garnet of diamond paragenesis is not found in the entire selection. 
Results of studying garnets from the three principal kimberlite fields by comprehensive method are summaried below.

1. Garnet of Zolotitsky field. Object of study is garnet from 7 pipes: 1) Pionerskaya, 2) Karpinsky, 3) Lomonosov, 4) Pomorskaya, 5)Pervomaiskaya, 6) Koltsovskaya, 7) Arkhangelskaya.

Morphology has been determined for 10000 grains of garnets. There is a prevalence in the diatremes of Zolotitsky field of lilac and red garnets. Garnets are represented by whole grains of fragments of round and oval shaped grains with knobby uneven or, otherwise, even, mat surface. A limited number of pink and orange garnets was found as splinters and fragments with an even mat surface. In the upper horizons of kimberlite pipes whole, round or oval shaped grains of pink and orange colours occur with finely corroded even surface. Further studies of such samples made it possible to establish their non-kimberlitic origin.

400 samples of garnets were examined at the second stage of using the optic-spectroscopic method. Further electron microprobe examination of garnets made it possible to prove the boundaries of paragenetic types of occurrence on the modified color diagram.

Database of Zolotitsky field garnets includes classification on this mineral on the basis of 546 electron-probe analyses. With the application of discriminant analysis with variations of earlier determined chemical -genetic classification, it became possible to determine main chemical-genetic groups of garnets in Zolotitsky field. The distribution garnets of different parageneses are on the Fig. $7.5 \%$ of all studied garnets occur in high grade diamond bearing rocks and $58 \%$ of garnets occur in diamond bearing rocks. It is worth mentioning that there was found a high occurrence of garnets of diamond bearing parageneses from eclogitic rocks $(8.9 \%$ out of $9.1 \%$ of all studied garnets having eclogitic paragenesis).

2. Garnet of Verkhotinsky field. The studied grains of garnet were collected from heavy concentrate out of 4 kimberlite pipes: 1 ) Volchia-Severnaya; 2) Osetinskaya; 3) Maiskaya; 4) Verkhotina.

900 grains of garnets were studied to determine their morphology. Most of the garnets are pink and orange. The feature which is common for all studied samples is the existence of multiple primary cracks in the mineral and other grain defects, caused by hydrothermal corrosion.

The database for garnets from Verkhotinsky field includes the results of 110 analyses. The results of the discriminant analysis are on the Fig. It should be noted that the content of garnets from metamorphic rocks is relatively high $(29 \%)$ which is more than in the diatremes of Zolotitsky field. The content of mantle rocks in the kimberlite pipes of Verkhotinsky field is more limited than in Zolotitsky field. $6.5 \%$ of all studied garnets occur in high grade diamond bearing rocks and $57.5 \%$ of garnets occur in diamond bearing rocks ( $51 \%$ of all studied garnets have ultrabasic paragenesis and $6.5 \%$ have eclogitic paragenesis).

3. Garnet of Kepinsky field. Object of study is garnet from three main groups of kimberlitic bodies: 1) Shochinsky, 2) Kepinsky, 3) Soyansky. The studies revealed the morphology of approximately 300 grains from Shochinsky pipe, 900 grains from diatremes of Kepinsky group of bodies and 1800 grains from pipes of Soinsky group. Garnets of round and oval shapes with knobby or evenly, mat surfaces prevail in all bodies. Garnets of Shochinsk field are pink and orange, while in the diatremes of Kepinsky and Soinsky groups they are red and lilac. It should be noted that many samples of garnets are characterised by a high degree of kelyphytisation.

Database concerning the composition of garnets was formed of 400 analyses. All garnets of Kepinsky field were divided into 12 chemical-genetic groups, and there are groups of garnets connected with ilmenite rocks (Fig.). $22 \%$ of all studied garnets were the garnets from metamorphic rocks. $6.5 \%$ of all studied garnets occur in high grade diamond bearing rocks and $54 \%$ of garnets occur in diamond bearing rocks ( $36 \%$ of all studied garnets have ultrabasic paragenesis and $17 \%$ have eclogitic paragenesis). 


\section{Summary}

By the complex study of garnets it was detected a great diamond potential of Zolotitsky field pipes, lesser - for Verkhotinsky and Kepinsky fields. It was established types of diamondiferous parageneses and quantitative relations between types of deep rocks. The express-methology allows to study a statisticaliy representative of the rocky material causes the necessity for the wide introduction in the scientific-production organizations. The new methodology makes possible to pasportize bodies of kimberlites and lamproites, to localize the aureoles, to evaluate diamond potential of newly discovered kimberlite and lamproite bodies, to study the horizontal and vertical zonality of the latter and so on.

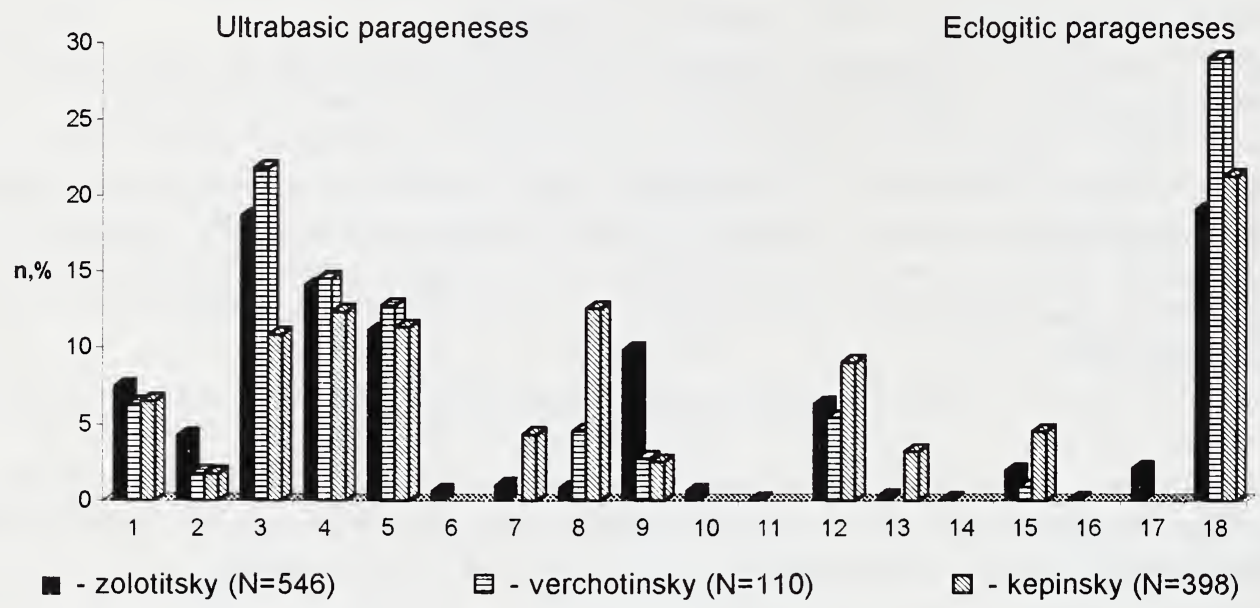

Fig. H istogram of distribution chemical-genetic groups of gamets from Zolotitsky (1), Verkhotinsky (2) and Kepinsky fields. $\mathrm{N}$ - number of studied garmet grains, $\mathrm{n}$ - frequency of ocaurence in \%. 1 - highly diamondiferous dunites and harzburgites; 2 diamond bearing peridotite with high and meduim chromium garnet; 3 - diamond bearing equigranular lherzolites with highly chromium gamet; 4 - diamond bearing equigranular lherzolites with medium chromuim gamet; 5 - diamond bearing equigranular lherzolites with low and meduim gamet; 6 - diamond bearing wehrlite; 7 - low grade diamond bearing lherzolites with high content of chromium, titanium and calcium gamet; 8 - low grade diamond bearing equigranular (sometimes shared) ilmenite lherzolites with low chromium titanium gamet; 9 - lherzolites and websterites with low chromium gamet; 10 magnesian-iron ilmenite pyroxenite; 11 - magnesian alcremite; 12 - ilmenite-nutile diamondiferous magnesium-iron eclogite; 13 - diamondiferous magnesium-iron eclogite; 14 - diamondiferous aluminium eclogite; 15 - diamondiferous magnesium ilmenite-nutile eclogite; 16 - eclogite-like rock; 17 - gamets of contraversial genesis; 18 - gamets from metamorphic rock

\section{References}

Garanin, V.K., Kudriavtseva, G.P. et al. 1991. The inclusions in diamonds and diamondiferous rocks. Moscow, MSU. 239p.

Sablukov, S.M. 1995. Volcanic rocks of Zimny Bereg and petrological characteristics of diamondiferous Kimberlites. Summary of Thesis for Geological Science doctorate degree. Moscow: TsNIGRI publishers.24 p.

Verichev, E.M., Garanin, V.K. et al. 1991. Geology, Mineralogy and Petrology of Kimberlites of the Arkhangelsk Province. Geology and Prospecting. Moscow, N4, p.88-91. 